\title{
URGENSI PENERAPAN MEDIASI PENAL SEBAGAI ALTERNATIF PENYELESAIAN PERKARA PIDANA RINGAN DI LUAR PENGADILAN
}

\author{
Dwiasih Nadyanti, Putri Nabila K. A., Tiara Jayaputeri \\ Fakultas Hukum, Universitas Tarumanagara
}

\begin{abstract}
ABSTRAK
Bagi para pihak yang terlibat dalam perkara tindak pidana ringan, baik korban maupun pelaku hendaknya diperkenalkan dengan mekanisme Mediasi dan Peradilan Restoratif atau Restorative Justice sebagai salah satu upaya penanganan dengan Mediasi Penal yang sudah dipraktikkan sebagai penyelesaian Sengketa Alternatif di berbagai negara dan telah membawa hasil yang positif, baik bagi korban, pelaku, dan masyarakat. Berkenaan dengan upaya penerapan Mediasi Penal sebagai alternatif penyelesaian perkara tindak pidana ringan di luar pengadilan, dipertemukannya pelaku dan korban kejahatan secara langsung mengubah cara pandang hukum pidana yang selama ini dikenal statis dalam menyelesaikan sengketa dengan proses dan prosedur yang tetap kearah hukum pidana yang humanistis, karena dalam Mediasi Penal, fokus utamanya bukan pada pembalasan terhadap tindakan pelaku, tetapi ada pada upaya penyembuhan dan perdamaian. Maka dari itu, dalam setiap kebijakan penerapan mediasi penal sebagai alternatif penyelesaian perkara pidana di luar Pengadilan bagi tindak pidana ringan harus dipertimbangkan sebagai nilai, serta pembaharuan hukum pidana diharapkan berorientasi pada pendekatan nilai-nilai yang hidup dalam masyarakat Indonesia maupun negara lain yang dapat dipakai sebagai acuan dalam pembaharuan hukum pidana nasional Indonesia.
\end{abstract}

Kata kunci: Tindak Pidana Ringan, Mediasi Penal, Pembaharuan Hukum.

\begin{abstract}
Both offenders and victims who get involved in misdemeanors should use mediation and restorative justice mechanism. This approach is one of the efforts to settle disputes which is applied in some countries and brings several positive impacts for the victims, offenders, as well as society. Penal mediation, in its implementation, is an instrument to settle misdemeanors in non-judicial mechanisms enable the offenders and the victims to make a deal for what the offenders have done. This mechanism changes the popular belief in which the criminal law has been a strict instrument. In penal mediation, the settlement focuses on the effort of restitution to establish peace. Therefore, as a non-judicial dispute settlement, penal mediation should be considered as a value. Further, the lawmakers should put the social-based approach in the agenda of Indonesian criminal law reform.
\end{abstract}

Keywords: misdemeanor, penal mediation, legal reform 


\section{PENDAHULUAN}

Hukum yang berlaku pada masyarakat senantiasa mengalami pembaharuan mengikuti perkembangan kehidupan sehingga menjadikan hukum sangat beragam macamnya. Kemudian hukum dapat dikaji dari berbagai aspek-aspek tertentu. Oleh sebab itu apabila ditinjau dari aspek fungsinya maka salah satu ruang lingkup hukum publik adalah hukum pidana yang secara esensial dibagi menjadi hukum pidana materiil (materiel strafrecht) dan hukum pidana formal (formeel strafrecht). ${ }^{1}$

Menurut Barda Nawawi Arief, pembaharuan hukum pidana harus dilakukan dengan pendekatan kebijakan, karena pada hakikatnya pembaharuan hukum pidana hanya merupakan bagian saja dari kebijakan atau politik hukum pada umumnya dan khususnya bagian dari politik hukum pidana (criminal law/penal policy atau strafrechtpolitiek). ${ }^{2}$ Politik hukum merupakan bagian tak terpisahkan dari politik penegakan hukum, politik kriminal dan politik sosial. Oleh karena itu, di dalam setiap kebijakan dipertimbangkan sebagai nilai, maka pembaharuan hukum pidana diharapkan berorientasi pada pendekatan nilai-nilai yang hidup dalam masyarakat Indonesia maupun negara lain yang dapat dipakai sebagai acuan dalam pembaharuan hukum pidana nasional Indonesia. ${ }^{3}$

Berdasarkan "International Penal Reform Conference" yang diselenggarakan di Royal Holloway College, University of London, pada tanggal 13 - 17 April 1999 dikemukakan bahwa salah satu unsur kunci dari agenda baru pembaharuan hukum pidana (the key elements of a new agenda for penal reform) ialah perlunya memperkaya sistem peradilan formal dengan sistem atau mekanisme informal dalam penyelesaian sengketa yang sesuai dengan standarstandar hak asasi manusia (the need to enrich the formal judicial system with informal, locally based, dispute resolution mechanisms which meet human rights standards). Konferensi ini juga mengidentifikasikan Sembilan strategi pengembangan dalam melakukan pembaharuan hukum pidana, yaitu mengembangkan/membangun restorative justice; alternative dispute resolution;

\footnotetext{
${ }^{1}$ Lilik Mulyadi, Bunga Rampai Hukum Pidana Perspektif, Teoretis dan Praktik, (Bandung: Alumni, 2008), hal. 1.

${ }^{2}$ Barda Nawawi Arief, Bunga Rampai Kebijakan Hukum Pidana, (Bandung: Citra Aditya, 1996), hal. 54-55.

${ }^{3}$ Ibid.
} 
informal justice; alternative to custody; alternative ways of dealing with juveniles; dealing with violent crime; reducing the prison population; the proper management of prisons; dan the role of civil society in penal reform. ${ }^{4}$

Dalam upaya memberikan keadilan bagi para pihak yang terlibat dalam perkara pidana, terutama yakni tindak pidana ringan, baik korban maupun pelaku, hendaknya diintrodusir mekanisme mediasi dan peradilan restoratif (restorative justice). Sebagai salah satu upaya penangananya dengan mediasi penal yang sudah dipraktikkan sebagai penyelesaian sengketa alternatif di berbagai negara dan telah membawa hasil yang positif, baik bagi korban, pelaku dan masyarakat. Negaranegara yang telah mempraktikkan mediasi penal meliputi negara-negara anggota Uni Eropa (Prancis, Jerman, Austria, Belgia dan Polandia), Amerika Serikat, Jepang, Polandia, Slovenia, Canada, Norwegia, Denmark, Finlandia, dan Australia. $^{5}$

Mediasi penal dimaksudkan untuk mempertemukan antara pelaku tindak pidana dengan korban, oleh karenanya mediasi penal ini sering juga dikenal dengan istilah "Victim Offender Mediation" (VOM), Täter Opfer Ausgleich (TOA), atau Offender Victim Arrangement (OVA). ${ }^{6}$ Mediasi penal sebagai alternatif penyelesaian perkara pidana di luar prosedur peradilan pidana atau menjadi bagian dari mekanisme peradilan pidana di Indonesia mempunyai prospek yang cukup baik berdasarkan beberapa pertimbangan, yang salah satunya adalah mediasi penal telah direkomendasikan oleh PBB sebagai alternatif penyelesaian perkara pidana di luar pengadilan untuk mengatasi dampak negatif operasionalisasi peradilan pidana. ${ }^{7}$

Trisno Raharjo dengan mengutip Martin Wright mengatakan mediasi, merupakan suatu proses dimana korban dan pelaku kejahatan saling bertemu dan berkomunikasi, serta dengan bantuan pihak ketiga, langsung atau tidak, memudahkan korban untuk mengekspresikan apa yang menjadi kebutuhan dan

\footnotetext{
${ }^{4}$ Barda Nawawi Arief, Mediasi Penal: Penyelesaian Perkara Pidana di Luar Pengadilan, (Semarang: Penerbit Pustaka Magister, 2012), hal. 13-14.

${ }^{5}$ Mansyur Ridwan, Mediasi Penal Terhadap Perkara KDRT (Kekerasan Dalam Rumah Tangga), (Jakarta: Yayasan Gema Yustisia Indonesia, 2010), hal. 166.

${ }^{6}$ Barda Nawawi Arief, Kebijakan Legislatif Dalam Penanggulangan Kejahatan dengan Pidana Penjara, (Semarang: Badan Penerbit, Universitas Diponegoro, 1996), hal. 16

${ }^{7}$ Salman Luthan. 2011. "Mediasi Penal: Dalam Sistem Peradilan Pidana", Makalah disampaikan pada diskusi Mediasi Penal dalam Sistem Peradilan Pidana Indonesia yang diselenggarakan oleh Mahkamah Agung RI di Semarang, 25- 27 Mei 2011.
} 
perasaannya, dan memungkinkan pelaku menerima dan bertanggung jawab atas perbuatannya. Mediasi penal dikembangkan atas dasar prinsip kerja atau working of principles yang meliputi: ${ }^{8}$

a. Penanganan Konflik (Conflict Handling)

Mediator memiliki tugas untuk membuat para pihak melupakan kerangka hukum dan mendorong para pihak untuk ikut terlibat dalam proses komunikasi. Hal ini didasarkan pada ide, kejahatan yang telah menimbulkan konflik interpersonal. Konflik itulah yang dituju oleh proses mediasi.

b. Berorientasi Pada Proses (Process Orientation)

Mediasi lebih berorientasi pada kualitas proses dibandingkan dengan hasil yang didapatkan, yaitu antara lain menyadarkan pembuat delik akan kesalahannya, kebutuhan-kebutuhan konflik terpecahkan, ketenangan korban dari rasa takut.

\section{c. Proses Informal (Informal Proceeding)}

Mediasi penal merupakan suatu proses yang informal, tidak birokratis dimana menghindari prosedur hukum yang ketat.

Mediasi penal ini pun pada awalnya muncul karena sejalan dengan kultur masyarakat Indonesia yang dipelopori oleh Founding Fathers yakni, musyawarah mufakat dalam mengambil keputusan. Seiring perkembangannya, hal ini telah menjadi sebuah terobosan hukum yang mempunyai manfaat banyak bagi kedua belah pihak yang berperkara dan memberikan keuntungan tersendiri bagi pelaku dan korban.

Mediasi penal sendiri untuk pertama kali dikenal dalam peristilahan hukum positif di Indonesia sejak dikeluarkannya Surat Kapolri No. Pol: B/3022/XII/2009/SDEOPS tanggal 14 Desember 2009 tentang Penanganan Kasus Melalui Alternative Dispute Resolution (“ADR”), meskipun sifatnya parsial. Surat Kapolri ini menekankan bahwa penyelesaian kasus pidana dengan menggunakan ADR, harus disepakati oleh pihak-pihak yang berperkara namun apabila tidak terdapat kesepakatan baru diselesaikan sesuai dengan prosedur hukum yang berlaku secara profesional dan proporsional.

\footnotetext{
${ }^{8}$ Ahmad Ubbe, "Peradilan Adat dan Keadilan Restoratif", Jurnal Media Hukum Nasional, Volume 2 Nomor 2, Agustus 2013, hal. 8.
} 
Walau sejatinya mediasi penal belum memiliki payung hukum dalam sistem peradilan pidana Indonesia, mediasi penal menjadi sangat penting untuk diangkat dan digunakan dalam penanganan perkara pidana khususnya tindak pidana ringan. ${ }^{9}$

\section{METODE PENELITIAN}

Pada penelitian ini, penulis menggunakan metode penulisan yuridis normatif, dimana penulis meneliti dengan menggunakan teori hukum, kajian pustaka, dan peraturan perundang-undangan. Pendekatan yang digunakan adalah: pendekatan komparatif (comparative approach) dan pendekatan konseptual (conseptual approach). Sedangkan untuk menganalisa, penulis menggunakan 2 (dua) teknik pengolahan data, yaitu: teknik deskriptif dan teknik Interpretasi Hukum. Penulis juga menggunakan 3 (tiga) sumber bahan hukum, dengan bahan hukum primer yaitu Kitab Undang-Undang Hukum Pidana, Undang-Undang Nomor 8 Tahun 1981 tentang Kitab Undang-Undang Hukum Acara Pidana, dan Undang-Undang Nomor 2 Tahun 2002 tentang Kepolisian Negara Republik Indonesia.

\section{PEMBAHASAN}

\section{A. Proses Pelaksanaan Mediasi Penal Sebagai Penyelesaian Perkara Tindak Pidana Ringan di Luar Pengadilan}

Dalam pembahasan mengenai hukum, maka sejatinya harus melibatkan masyarakat, karena hukum dan masyarakat adalah satu kesatuan yang tidak dapat dipisahkan. Von Savigny yang merupakan salah satu tokoh dan pakar di bidang mazhab sejarah hukum (historical school of jurisprudence) mengemukakan pengertian hukum yang terkenal yaitu, "Das Recht wird nicht gemacht estist und

\footnotetext{
${ }^{9}$ Mys, "Siapa Bilang Kasus Pidana Tak Bisa Dimediasi”, http://www.hukumonline.com/ berita/baca/lt4e3a134f943cb/siapa-bilang-kasus-pidana-tak-bisa-dimediasi, 4 Agustus 2011, diakses pada tanggal 26 Juli 2018.
} 
wird mit dem volke" (hukum itu tidak dibuat, melainkan berkembang dan tumbuh bersama masyarakat). Mazhab sejarah yang kemudian menjadi sangat lekat dengan Savigny tidak menjadikan hukum sebagai sesuatu yang statis atau bahkan ketinggalan zaman atau old fashion. Hukum akan senantiasa dinamis, karena ia merupakan produk dari spirit dan jiwa bangsa Indonesia yang senantiasa berubah dan dinamis.

Dalam pelaksanaan hukum dalam kehidupan masyarakat sehari-hari, mempunyai arti yang sangat penting karena hukum diciptakan untuk mewujudkan keadilan, kepastian, dan memberikan manfaat bagi masyarakat. Bukan hanya jargon semata, ketiganya harus dapat diimplementasikan pada pelaksanaan hukum itu sendiri dalam masyarakat secara konkret. Hukum harus dipatuhi semua orang, dan semua orang harus diperlakukan sama di depan hukum atau kerap dikenal dengan equality before the law.

Mekanisme penegakan hukum dalam sistem peradilan pidana di Indonesia mengacu pada Undang-Undang Nomor 8 Tahun 1981 tentang Kitab UndangUndang Hukum Acara Pidana (KUHAP) yang membahas perihal tata cara atau prosedur sistem peradilan Indonesia yang dikenal sebagai Hukum Acara Pidana untuk menegakkan Hukum Pidana Materiil. Penegakan hukum pidana dimulai dari proses penyidikan di kepolisian, penuntutan oleh Jaksa Penuntut Umum, dan vonis hukuman atau sanksi oleh Hakim, yang pada intinya penegakan hukum adalah salah satu bentuk penjatuhan hukuman (pidana).

Dalam sistem hukum Indonesia yang merupakan warisan dari kolonial Belanda, memiliki ciri bahwa pelaksanaan pidana pada hakikatnya tidak terlepas dari kemauan masyarakat maupun kemauan negara untuk menciptakan rasa aman, tentram, dan damai dalam menjalani kehidupan sehari-hari. Sifat publik yang dimiliki hukum pidana menjadikan konsekuensi bahwa hukum pidana itu bersifat nasional. Dengan demikian, maka hukum pidana Indonesia diberlakukan ke seluruh wilayah negara Indonesia.

Di samping itu, mengingat materi hukum pidana yang kerap kental dengan nilai-nilai kemanusiaan, mengakibatkan hukum pidana seringkali digambarkan sebagai pedang bermata dua. Dimana, satu sisi hukum pidana bertujuan menegakkan nilai kemanusiaan, namun di sisi lain penegakan hukum pidana itu 
justru akan memberikan kesedihan bagi pelaku yang melanggarnya. Maka dari iru, kemudian pembahasan mengenai materi hukum pidana dilakukan dengan ekstra atau amat sangat hati-hati, yaitu dengan memerhatikan konkteks masyarakat dimana hukum pidana diberlakukan dan tetap menjunjung tinggi nilai kemanusiaan yang beradab.

Kepolisian sebagai lembaga yang menjadi outlet atau ujung tombak terakhir dalam penegakan hukum pidana memiliki tugas dan kewenangan apakah suatu perbuatan itu perlu dihentikan proses pengadilan pidana dengan keadaan-keadaan tertentu. Dasar hukum yang digunakan adalah Pasal 18 ayat (1) Undang-Undang Nomor 2 Tahun 2002 tentang Kepolisian Negara Republik Indonesia, yang berbunyi "untuk kepentingan umum dan masyarakat, pejabat Kepolisian Negara Republik Indonesia dalam melaksanakan fungsi, tugas, dan wewenangnya dapat bertindak menurut penilaiannya sendiri.”. Lebih lanjut dijelaskan dalam ayat (2) nya, pelaksanaan ketentuan sebagaimana dimaksud dalam ayat (1) hanya dapat dilakukan dalam keadaan-keadaan yang sangat perlu dengan memperhatikan peraturan perundang-undangan, serta Kode Etik Profesi Kepolisian Negara Republik Indonesia.

Seperti yang sudah diterangkan di atas, dalam sistem peradilan pidana Indonesia yang berlandaskan pada UU No. 8 Tahun 1981 tentang Hukum Acara Pidana (KUHAP), sistem peradilan pidana itu diawali di kepolisian, kejaksaan, dan hakim pada saat peradilan. Dalam proses sistem peradilan pidana memakan waktu yang cenderung lama serta panjang dan bahkan berbelit-belit, sehingga sangat dibutuhkan sebuah terobosan hukum yang dapat menggunakan mediasi penal.

Secara umum, mediasi penal merupakan sebuah langkah terobosan hukum dalam rangka pembaharuan hukum pidana yang erat hubungannya dengan restorative justice. Penggunaan mediasi penal sebagai alternatif peradilan pidana khususnya daam tindak pidana ringan bukan merupakan hal yang dapat dibilang baru dan bukan merupakan suatu jeharusan untuk diimplementasikan secara langsung. Namun, seperti yang Savigny katakan bahwa hukum akan senantiasa berubah dan dinamis. Maka dari itu, mediasi penal yang merupakan terobosan 
hukum mempunyai manfaat yang banyak bagi kedua belah pihak yang berperkara dan memberikan keuntungan tersendiri kepada pelaku dan korban.

Dalam penanganan kasus pidana, apabila dilihat tidak dengan terperinci, mediasi penal hampir sama dengan yang dikenal sebagai diksresi (discretion) yang dimiliki oleh lembaga sistem peradilan pidana Indonesia, seperti kepolisian dan kejaksaan untuk menyaring kasus-kasus yang masuk untuk tidak meneruskan sebagian kasus tertentu melalui proses peradilan pidana. Namun, tdalam mediasi penal erdapat fundamental yang berbeda dengan sistem diskresi tersebut.

Mediasi penal cenderung lebih mengedepankan kepentingan pelaku tindak pidana dan sekaligus korban, sehingga tercapai win-win solution yang menguntungkan para pihak. Dalam mediasi penal, korban dipertemukan secara langsung dengan pelaku tindak pidana ringan dan dapat mengemukakan tuntutannya sehingga menghasilkan perdamaian para pihak.

Lebih lanjut, perihal Tindak Pidana Ringan atau kerap disebut (“Tipiring”) diatur dalam Pasal 205 ayat (1) KUHAP, yang mengatakan bahwa yang diperiksa menurut acara pemeriksaan tindak pidana ringan ialah perkara yang diancam dengan pidana penjara atau kurungan paling lama 3 (tiga) bulan dan atau denda sebanyak-banyaknya Rp 7.500,- dan penghinaan ringan kecuali yang ditentukan dalam paragraf 2 (dua) bagian ini. KUHAP hanya melanjutkan pembagian perkara atau pemeriksaan yang sudah diketahui sebelumnya dalam Herzien Inlandsch Reglement atau HIR. Hal ini juga terwujud dalam sudut penempatannya dalam KUHAP, yaitu Tipiring masuk ke dalam Acara Pemeriksaan Cepat, bersama-sama dengan perkara pelanggaran lalu lintas jalan. Pengaturan tersebut dapat dimengerti karena Tipiring pada umumnya adalah tindak pidana (delik) pelanggaran yang dalam Kitab Undang-Undang Hukum Pidana ditempatkan pada buku III. Dapat diambil kesimpulan bahwa hakikat Tipiring adalah tindakan-tindakan pengaduan Acara Pemeriksaan Tindak Pidana Ringan agar perkara dapat diperiksa dengan prosedur yang lebih sederhana.

Berdasarkan pemaparan di atas, mediasi penal merupakan salah satu jalan alternatif yang dinilai tepat untuk menyelesaikan kasus Tipiring. Melalui mediasi penal, proses penanganan perkara dilakukan secara transparan, sehingga dapat mengurangi juga penyimpangan yang seringkali terjadi dalam pengadilan pidana 
tradisional. Mengingat banyaknya keuntungan yang ada pada mediasi penal, sebagaimana telah dipraktekkan di beberapa negara, maka dibutuhkan upaya berupa kajian untuk menerapkan mediasi penal dalam peradilan pidana Indonesia bagi Tipiring sebagai bagian dari sistem peradilan pidana di Indonesia.

Menteri Hukum dan Hak Asasi Manusia periode 2014 - 2019, Yasonna Laoly mengatakan bahwa usulan agar narapidana kasus Tipiring tidak perlu mendapat hukuman kurungan. Ia memaparkan bahwa setiap bulan terdapat 2.000 tambahan narapidana yang masuk ke lapas. Sehingga, dirinya berharap implementasi restorative justice dapat segera dibakukan. Selain itu, Ia juga khawatir apabila para terpidana dengan hukuman kecil masuk ke lapas, akan bertambah buruk dalam perilakunya karena terekspos perilaku narapidana lainnya.

Urgensi mediasi penal untuk diimplementasikan ke dalam sistem peradilan pidana Indonesia sangat dibutuhkan, karena: ${ }^{10}$

a. Diharapkan dapat mengurangi penumpukan perkara;

b. Merupakan salah satu proses penyelesaian sengketa yang dianggap lebih cepat, murah dan sederhana;

c. Dapat memberikan akses seluas mungkin kepada para pihak yang bersengketa untuk memperoleh keadilan; dan

d. Memperkuat dan memaksimalkan fungsi lembaga pengadilan dan penyelesaian sengketa di samping proses menjatuhkan pemidanaan.

Ketika mediasi penal dikaitkan dengan ide keadilan restoratif atau restoratice justice dan diskresi, dapat dikatakan bahwa nilai-nilai yang menjadi fundamental atau mendasari mediasi penal adalah restorative justice, sedangkan roh mediasi penal untuk mewujudkan restorative justice ada pada tiap-tiap institusi penegak hukum. Hal ini dapat diketahui seperti halnya seorang jaksa memiliki deponeering atau dikenal dengan penyampingan perkara demi kepentingan umum yang merupakan wewenang yang diberikan undang-undang kepada Jaksa, dalam hal ini Jaksa Agung, dan polisi memiliki discretion. Dengan demikian, diskresi yang dimiliki institusi kepolisian merupakan roh atau sesuatu yang dapat menghidupkan atau setidaknya menjadi sumber inspirasi dimana mediasi penal dapat diimplementasikan dalam tahap penyelidikan oleh kepolisian

10) Ds. Dewi dan Fatahillah A. Syukur, Mediasi Penal: Penerapan Restorative Justice di Pengadilan Anak Indonesia, (Indie Publishing, Jakarta, 2011), hal. 80. 
sehingga akan terbentuk sistem kedamaian bagi para pihak yang berperkara, serta dapat mewujudkan rasa keadilan yang dapat memulihkan para pihak dan masyarakat secara umum.

Mediasi penal memiliki empat tahap dalam pelaksanaanya. Pertama adalah fase masukan (in take), dimana pada fase ini mediator mempelajari konflik dari para pihak dan harus menentukan apakah pelanggaran yang terjadi pada para pihak memang dapat diadakan mediasi. Mediator dapat menyatakan bahwa konflik tersebut tidak dapat diselesaikan dengan mediasi ketika korban ketakutan berbicara langsung kepada pelaku, merasa tersakiti jika berkomunikasi dengan pelaku dan pelaku tidak mau mengakui keterlibatannya dalam konflik atau perbuatan tersebut. Mediator juga memastikan keamanan fisik dan emosi korban tetap terjaga, sehingga jika hal itu tidak terpenuhi, maka mediator harus menolak menyelesaikan konflik tersebut dengan mediasi untuk mencegah terjadinya reviktimisasi. ${ }^{11}$

Kedua adalah fase persiapan konfrontasi (confrontation). Konfrontasi dilaksanakan dengan beberapa acara, tergantung apakah akan digunakan social work case development model atau pure mediation model. Untuk model yang pertama, banyak orang yang akan dipersiapkan atas konfrontasi korban pelaku dan mediator harus membantu para pihak dalam mengidentifikasi kebutuhan mereka. Mediator akan menemui para pihak sebelum sesi mediasi dilaksanakan untuk merekomendasikan bantuan professional dan membantu mereka mengidentifikasi tujuan dan kontribusi mereka dalam proses mediasi. Sedangkan model yang kedua, yakni model mediasi murni, menolak bahwa mediator harus menemui para pihak sebelum proses mediasi dilaksanakan karena kegiatan itu akan menimbulkan hubungan yang kurang baik antara mediator dengan para pihak. Model ini menyarankan mediator untuk menghubungi para pihak melalui telepon atau surat yang dikirim melalui pos. ${ }^{12}$

Ketiga adalah fase mediasi itu sendiri (mediation its self), pada fase ini mediasi lebih difokuskan pada dialog daripada pemenuhan kesepakatan pemberian restitusi, memunculkan rasa empati dan pemahaman antara korban dan

\footnotetext{
${ }^{11}$ Russel E. Farbiarz, Victim-Offender Mediation: A New Way of Disciplining America's Doctors, (Michigan State University Journal of Medicine \& Law: No.12, 2008), hal. 366.

${ }^{12}$ Alyssa H. Shenk, op.cit. hal. 194-195
} 
pelaku. Fase ini dimulai dengan aturan main yang harus diikuti kedua belah pihak, kemudian dilanjutkan dengan pemberian kesempatan kepada korban untuk menceritakan kejahatan yang menimpanya. Setelah itu, pelaku juga diberi kesempatan untuk merespon keluhan-keluhan korban, menjelaskan mengapa kejahatan itu terjadi serta meminta maaf. Pembicaraan mengenai kerugian korban, kesepakatan reparasi yang memuaskan kedua belah pihak merupakan langkah berikutnya yang harus dijalankan oleh mediator. ${ }^{13}$

Terakhir adalah fase pelaksanaan hasil kesepakatan (outward). Dimana pada fase ini jika perjanjian telah disepakati kedua belah pihak, baik pelaku maupun korban, pelaku kejahatan dipantau untuk memastikan bahwa perjanjian tersebut dilaksanakan tanpa pengurangan sedikit pun. Pelaku harus dipastikan bahwa dia mematuhi perjanjian yang telah disepakatinya dengan korban. ${ }^{14}$

Mediasi penal ini memiliki manfaat yang dapat dirasakan oleh pelaku dan korban. Bagi korban, model ini dapat menyembuhkan baik secara emosi maupun psikis melalui pertemuan dan komunikasi dengan pelaku. Korban pun berhak menuntut restitusi kepada pelaku, walau hal itu bukanlah tujuan utama dari adanya suatu mediasi. ${ }^{15}$

Bagi pelaku, setidaknya ia dapat mengakui bahwa kejujuran dan keadilan dalam proses mediasi ini memberikan respon positif baginya, sehingga pelaku merasa memiliki hubungan yang dekat dengan korban. Dalam konteks ini, pengakuan bersalah atas tindakannya menjadi hal yang mudah terjadi, karena kemauan korban untuk mendengar penjelasan atas tindakannya itu sudah merupakan suatu hal yang positif baginya, dimana hal ini tidak ditemukan dalam sistem peradilan pidana.

Selain memiliki kelebihan yang langsung dapat dirasakan oleh para pihak, mediasi penal tetap memiliki kelemahan. Pertama, tidak adanya panduan yang sesuai untuk memastikan bahwa proses mediasi penal berjalan secara efektif dan memenuhi prinsip-prinsip etif. Misalnya, kritik terhadap kurangnya pelatihan formal kepada mediator dalam praktik mediasi antara pelaku dan korban. Kegagalan untuk memberikan pelatihan yang memadai akan menyebabkan tidak

\footnotetext{
${ }^{13} \mathrm{Ibid}$.

${ }^{14}$ Russel E. Farbiarz, op.cit. hal. 367

${ }^{15}$ Ilyssa Wellikoff, op.cit. hal. 7-8
} 
jelasnya tujuan yang hendak dicapai dalam suaru mediasi. Kedua, perlindungan yang kurang memadai kepada korban, karena tidak sedikit korban yang mengalami reviktimasi ketika dihadapkan secara langsung dengan pelaku kejahatan. Ketiga, kedudukan yang tidak seimbang antara pelaku dan korban menjadikan proses mediasi tidak berlangsung dengan baik dan malah mengarah kepada kecenderungan yang tidak efektif. Mediasi hanya dapat dilaksanakan secara efektif jika kedua belah pihak memiliki kedudukan yang seimbang. ${ }^{16}$

\section{B. Upaya Penerapan Mediasi Penal Sebagai Alternatif Penyelesaian Perkara Tindak Pidana Ringan di Luar Pengadilan}

Pada proses peradilan pada perkara pidana yang berupaya secara maksimal untuk menemukan dan mewujudkan kebenaran materiil, kerap muncul keluhan ketidakadilan dari pihak yang berkepentingan atau stakeholder dalam perkara tersebut. Keterlibatan masyarakat sebagai salah satu atau komponen stakeholder dalam perkara pidana berbanding lurus dengan jangkauan tingkat berbahayanya kejahatan yang dilakukan. Lembaga masyarakat yang banyak menjadi stakeholder juga merupakan konsekuensi etis dari akibat yang ditimbulkan oleh kejahatan, sehingga menurut rasa pertanggungjawaban kolektif dari masyarakat, karena berbahayanya kejahatan berada dalam ranah publik. Atensi, empati, dan tanggung jawab stakeholder atas terjadinya kejahatan manusia terhadap manusia lainnya merupakan bagian dari sikap moral. Entitas tanggung jawab, niat, kesalahan, dan rasa bersalah merupakan fokus utama acuan hukum pidana dan proses pengadilan perkara pidana.

Perkembangan ide mediasi penal tidak lepas dari perkembangan restorative justice sebagai salah satu ide pembaharuan hukum pidana (penal reform), dikarenakan konsep mediasi penal pada dasarnya merupakan salah satu sarana dalam mewujudkan pelaksanaan konsep restorative justice dalam penyelesaian perkara pidana. Mediasi penal sebagai mekanisme penyelesaian perkara pidana dalam mewujudkan keadilan restoratif atau restorative justice.

Melalui proses mediasi penal, maka diperoleh puncak keadilan tertinggi akibat terjadinya kesepakatan antara kedua belah pihak yang terlibat dalam perkara pidana. Pihak korban maupun pelaku diharapkan dapat mencari dan

\footnotetext{
${ }^{16)}$ ibid. hal. 9
} 
mencapai solusi serta alternatif terbaik untuk menyelesaikan perkara tersebut. Implikasi dari pencapaian ini maka pihak pelaku maupun korban dapat mengajukan kompensasi yang ditawarkan, disepakati, dan dirundingkan antar mereka bersama sehingga, solusi yang didapatkan bersifat "win-win" atau secara harfiah dikenal solusi menang-menang. Selain itu, melalui mediasi penal ini akan memiliki implikasi yang bersifat positif karena secara filosofis, dicapainya peradilan dilakukan dengan cepat, sederhana, dan biaya ringan karena pihak yang terlibat relatif lebih sedikit dibandingkan melalui proses peradilan dengan komponen Sistem Peradilan Pidana (SPP). ${ }^{17}$

Aipda Aji Lukmansyah memaparkan mediasi dalam perkara pidana dapat dilakukan dalam bentuk langsung atau tidak langsung, yaitu dengan mempertemukan para pihak (korban dan pelaku) secara bersama-sama, atau mediasi yang dilakukan oleh mediator secara terpisah (kedua belah pihak tidak dipertemukan secara langsung). Hal ini dapat dilakukan oleh mediator. Mediasi dapat dilakukan dibawah pengawasan lembaga peradilan pidana atau organisasi berbasis masyarakat yang independen dan selanjutnya hasil mediasi penal dilaporkan kepada otoritas peradilan pidana.

Dalam hukum pidana, mediasi berarti proses penyelesaian perkara pidana dengan mempertemukan pelaku kejahatan dan korban untuk mencapai kesepakatan bersama berkaitan dengan kejahatan yang dilakukan pelaku dan restitusi yang diberikan kepada korban. Dipertemukannya pelaku dan korban kejahatan secara langsung mengubah cara pandang hukum pidana yang selama ini dikenal statis didalam menyelesaikan sengketa dengan proses dan prosedur yang tetap kearah hukum pidana yang humanistis, karena di dalam mediasi penal fokus utamanya bukan pada pembalasan terhadap tindakan pelaku, tapi pada upaya penyembuhan dan perdamaian. Pertemuan antara pelaku dan korban bertujuan untuk memperbaiki kerusakan atau kerugian, baik yang dialami korban, lingkungan maupun masyarakat luas.

Menurut Kasatreskrim Polres Malang Kota, Aji Lukmansyah, penerapan mediasi penal sebagai alternatif penyelesaian perkara pencurian sangat efektif dan efisien. Hal ini juga akan menciptakan adanya rasanya keadilan terhadap saksi,

${ }^{17}$ Lilik Mulyadi, "Mediasi Penal dalam Sistem Peradilan Pidana Indonesia", Jurnal Yustisia, Volume 2 Nomor 1, April 2013 hal. 2. 
korban, dan tersangka sehingga masyarakat puas atas pelayanan penyidik. Peradilan pidana sesungguhnya bukan merupakan institusi yang paling baik didalam menyelesaikan konflik antara korban dan pelaku. Hal demikian disebabkan oleh suatu konsepsi bahwa peradilan ternyata memiliki standar keadilan tersendiri terkait dengan pelaku kejahatan yang sama sekali tidak memperhatikan keinginan-keinginan korban. ${ }^{18}$ Penyelesaian konflik juga akan merusak hubungan kekeluargaan antara korban dan pelaku. Hubungan yang awalnya damai, tentram, harmonis dan bersifat kekeluargaan hancur dengan kehadiran sistem peradilan pidana. ${ }^{19}$

Selain itu dengan adanya penerapan mediasi penal bagi pelaku tindak pidana ringan, dapat menghapuskan stigma negatif masyarakat terhadap ex-convict, karena sebagai pelaku tindak pidana ringan yang dijatuhi hukuman pidana penjara dengan kurun waktu kurang dari 3 bulan, dapat menimbulkan stigma masyarakat yang negatif terhadapnya. Sehingga setelah dirilis dari lembaga pemasyarakatan tidak menutup kemungkinan mantan pelaku akan sulit untuk melanjutkan kehidupan seperti sedia kala.

Menurut Barda Nawawi Arief, pembaharuan hukum pidana harus dilakukan dengan pendekatan kebijakan, karena pada hakikatnya pembaharuan hukum pidana hanya merupakan bagian saja dari kebijakan atau politik hukum pada umumnya dan khususnya bagian dari politik hukum pidana (criminal law/penal policy atau strafrechtpolitiek). ${ }^{20}$ Politik hukum merupakan bagian tak terpisahkan dari politik penegakan hukum, politik criminal dan politik sosial. Oleh karena itu, di dalam setiap kebijakan-dalam hal ini penerapan mediasi penal sebagai alternatif penyelesaian perkara pidana di luar pengadilan bagi tindak pidana ringan harus dipertimbangkan sebagai nilai, maka pembaharuan hukum pidana diharapkan berorientasi pada pendekatan nilai-nilai yang hidup dalam masyarakat

18 Adina Levine, A Dark State of Criminal Affairs: ADR Can Restore Justice to the Criminal "Justice System", (Hamline Journal OF Public Law and Policy, 2004), hal. 118.

${ }^{19}$ Jack B. Weinstein, Some Benefit and Risks of Privatization of Justice Though ADR, (Ohio State Journal on Dispute Resolution: 1996), hal. 294.

${ }^{20}$ Barda Nawawi Arief, Bunga Rampai Kebijakan Hukum Pidana, (Bandung: Citra Aditya, 1996), hal. 54-55. 
Indonesia maupun negara lain yang dapat dipakai sebagai acuan dalam pembaharuan hukum pidana nasional Indonesia. ${ }^{21}$

Pembaharuan hukum pidana di Indonesia adalah upaya melakukan peninjauan dan rekonstruksi hukum pidana yang sesuai dengan nilai sentral sosiopolitik, sosio-filosofik, dan nilai sosio-kultural masyarakat Indonesia. Oleh karena itu penggalian nilai-nilai bangsa Indonesia dalam usaha pembaharuan hukum pidana Indonesia harus dilakukan agar hukum pidana Indonesia pada masa yang akan datang sarat dengan nilai-nilai sosio-kultural masyarakat Indonesia. ${ }^{22}$

Dengan tetap memberlakukan hukuman penjara bagi pelaku tindak pidana ringan, dana yang digunakan untuk memberi makan para pelaku tindak pidana ringan sejatinya dapat dialokasikan untuk pembangunan infrastruktur negara. Dilain sisi, pembinaan yang dijaminkan oleh lembaga pemasyarakatan pun baru dijalankan setelah 6 bulan masa hukuman. Sehingga bagi pelaku tindak pidana ringan yang dihukum dengan masa hukuman kurang dari 3 bulan hal tersebut tidak memberikan efek pembinaan, melainkan hanya memberikan efek penjera semata. Bahkan tidak menutup kemungkinan para pelaku tindak pidana ringan saat didalam lembaga pemasyarakatan mengenal tindak kejahatan lainnya yang dapat ia lakukan setelah ia bebas, dikarenakan stigma masyarakat yang telah begitu kental terhadapnya.

\section{PENUTUP}

1. Proses Mediasi penal terhadap perkara pidana ringan di luar pengadilan, terdapat 4 (empat) tahap dalam pelaksanaannya, yakni Fase masukan (in take), Fase persiapan konfrontasi (confrontation) dengan cara Social work case development model, Pure mediation model atau mediasi murni, Fase mediasi itu sendiri (mediation its self), Fase pelaksanaan hasil kesepakatan (outward). Kelebihan dari mediasi penal, yakni bagi korban dengan menyembuhkan emosi atau psikis. Bagi pelaku dengan mengakui bahwa

\footnotetext{
${ }^{21}$ Ibid.

${ }^{22}$ Ibid., hal. 163.
} 
kejujuran dan keadilan dalam proses mediasi ini memberikan respon positif baginya. Kelemahan dari mediasi penal, yakni tidak adanya panduan yang sesuai untuk memastikan bahwa proses mediasi penal berjalan secara efektif dan memenuhi prinsip-prinsip etif, Perlindungan yang kurang memadai kepada korban (mengalami reviktimasi). Kedudukan yang tidak seimbang antara pelaku dan korban, maka dari itu kedudukan korban dan pelaku diusahakan harus seimbang.

2. Dalam upaya penerapan mediasi penal sebagai alternatif penyelesaian perkara tindak pidana ringan di luar pengadilan dipertemukannya pelaku dan korban kejahatan secara langsung mengubah cara pandang hukum pidana yang selama ini dikenal statis didalam menyelesaikan sengketa dengan proses dan prosedur yang tetap kearah hukum pidana yang humanistis, karena di dalam mediasi penal fokus utamanya bukan pada pembalasan terhadap tindakan pelaku, tapi ada pada upaya penyembuhan dan perdamaian. Setiap kebijakan penerapan mediasi penal sebagai alternatif penyelesaian perkara pidana di luar pengadilan bagi tindak pidana ringan harus dipertimbangkan sebagai nilai, serta pembaharuan hukum pidana diharapkan berorientasi pada pendekatan nilai-nilai yang hidup dalam masyarakat Indonesia maupun negara lain yang dapat dipakai sebagai acuan dalam pembaharuan hukum pidana nasional Indonesia. 


\section{DAFTAR PUSTAKA}

\section{Buku}

Arief, Barda Nawawi. Bunga Rampai Kebijakan Hukum Pidana. Bandung: Citra Aditya Bakti, 1996.

Kebijakan Legislatif Dalam Penanggulangan Kejahatan dengan Pidana Penjara. Semarang: Badan Penerbit, Universitas Diponegoro.

- Mediasi Penal: Penyelesaian Perkara Pidana di Luar Pengadilan. Semarang: Penerbit Pustaka Magister, 2012.

Dewi DS dan Mansyur. Mediasi Penal: Penerapan Restorative Justice di Pengadilan Anak Indonesia. Jakarta: Indie Publishing, 2011.

Mulyadi, Lilik. Bunga Rampai Hukum Pidana Perspektif, Teoretis dan Praktik. Bandung: Alumni, 2008.

Ridwan, Mansyur. Mediasi Penal Terhadap Perkara KDRT (Kekerasan Dalam Rumah Tangga). Jakarta: Yayasan Gema Yustisia Indonesia, 2010.

\section{Artikel}

Alyssa H Shenk. "Victim Offender Mediation: The Road to Repairing Hate Crime Injustice”, Ohio State Journal on Dispute Resolution. 2001

Jack B Weinstein. "Some Benefit and Risks of Privatization of Justice Though ADR", Ohio State Journal on Dispute Resolution. 1996.

Levine, Adina, A Dark State of Criminal Affairs: ADR Can Restore Justice to the Criminal "Justice System", Hamline Journal Of Public Law and Policy,2004.

Russel E Farbiarz. "Victim-Offender Mediation: A New Way of Disciplining America's Doctors". Michigan State University Journal of Medicine \& Law: No.12. 2008.

Salman Luthan. "Mediasi Penal: Dalam Sistem Peradilan Pidana”, Makalah disampaikan pada diskusi Mediasi Penal dalam Sistem Peradilan Pidana Indonesia yang diselenggarakan oleh Mahkamah Agung RI di Semarang, 25- 27 Mei 2011. 2011. 
Ubbe, Ahmad, "Peradilan Adat dan Keadilan Restoratif", Jurnal Media Pembinaan Hukum Nasional, Volume 2, Agustus 2013. 